\title{
Reading Arabic Shallow and Deep Genres: Indispensible Variables to Science of Reading
}

\author{
Abdelaziz M. Hussien ${ }^{1}$ \\ ${ }^{1}$ Department of Curriculum \& Instruction, Faculty of Education, Suez Canal University, Ismailia, Egypt \\ Correspondence: Abdelaziz M. Hussien, Department of Curriculum \& Instruction, Faculty of Education, Suez \\ Canal University, Ismailia, Egypt. E-mail: damhussein@gmail.com
}

Received: December 11, $2013 \quad$ Accepted: January 6, $2014 \quad$ Online Published: February 19, 2014

doi:10.5539/jel.v3n1p60

URL: http://dx.doi.org/10.5539/jel.v3n1p60

\begin{abstract}
Most principles and propositions in the science of reading are derived from research on Latin orthographies, usually, in English while much less is known about Semitic orthographies, namely, Arabic. This study investigated the effect of vowels and type of genre on oral accuracy, oral rate, and oral comprehension in reading Arabic orthography. A convenience sample of 85 children (34 fifth male graders and 51 tenth male graders) was selected from two public schools in Saudi Arabia. The researcher developed two reading measures; the Fifth Grade Reading Measure and Tenth Grade Reading Measure. Each measure has two genres (informational and poetic) and two versions (shallow/vowelized and deep/unvowelized). Each child individually completed the two versions of the measure in his grade. The results revealed that the students read the shallow genres (informational and poetic) more accurately and with more comprehension but less rapidly than reading the deep genres. In addition, the students read the informational genre (shallow and deep) more accurately, rapidly, and with more comprehension than the poetic genre (shallow and deep). The discussion concludes that a) the nature of Arabic orthography, mainly vowels, is an indispensible variable to the literature of science of reading, b) oral reading accuracy, oral reading rate and oral reading comprehension are affected by the unique characteristics of the genre, and c) vowels in Arabic are important to improve oral reading accuracy, and oral reading comprehension for the first grades in primary school and later grades in secondary school as well.
\end{abstract}

Keywords: genres, vowels, Arabic orthography, oral reading accuracy, oral reading rate, oral reading comprehension

\section{Introduction}

It is unequivocal in the literature that reading accurately, rapidly and with comprehension requires processing of many variables, chief among them, the knowledge of language conventions and context (e.g., Abu Rabia \& Siegel, 1995; Stanovich, 1980, 1986, 1991; Stanovich \& Freeman, 1981).

\subsection{Orthographical Variables}

The nature of orthography is an important factor to be considered in the context of reading theory. Orthography consistency, letters and sounds conformities, seems to affect reading acquisition (Abu-Hajaj, 2006; Furnes \& Samuelsson, 2009; Georgiou, Parrila, \& Papadopoulos, 2008; Goswami, Ziegler, \& Richardson, 2005; Taibah \& Haynes, 2011). In contrast to some Latin orthographies e.g., English, Arabic is a consistent orthography with predictable correspondences in both sound-letter and letter-sound relations (Abu-Hajaj, 2006; Abu-Rabia, 1997, 2001; Abu-Rabia \& Siegel, 1995; Lervåg \& Hulme, 2010; Mahfoudhi, Everatt, \& Elbeheri, 2011; Seymour, Aro, \& Erskine, 2003; Taibah \& Haynes, 2011). Arabic orthography has 28 consonants with three long vowels and three short vowels. These short vowels are diacritics that are written according to and explain word pronunciation, meaning, and function in a sentence (Abu Rabia, 1998, pp. 105-106). Arabic script is presented, in most printed media, without visible short vowels and skilled readers are expected to deduce these vowels depending on context, but vowelized scripts should be presented to beginning readers (Abu-Rabia \& Taha, 2006; Hussien, 2014; Mahfoudhi et al., 2011; Taibah \& Haynes, 2011). The important issue here is that Arabic is a shallow orthography, if presented vowelized, and is a deep orthography, if introduced unvowelized (Abu-Rabia, 2000; Abu-Rabia \& Siegel, 2003; Abu-Rabia \& Taha, 2006; Mahfoudhi et al., 2011; Mohamed, Elbert, \& Landerl, 2011). The current study examined the effect of both vowelized and unvowelized genres, informational and poetic, on oral reading accuracy, oral reading rate, and oral reading comprehension. 
In addition, Arabic is a very homographic script in its words (Abu-Rabia \& Siegel, 1995, 2003). Words with identical forms, isolated or in connected text, can have different meanings and pronunciations. Thus, visible short vowels are used to show the accurate meaning and pronunciation of a word (Abu-Rabia, 1998, p. 107) e.g.,

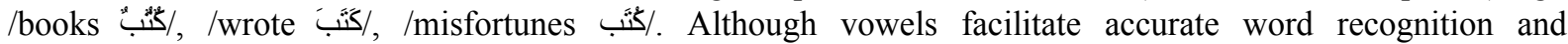
comprehension (Abu Rabia, 1997, 1998, 1999, 2001) much less attention has been given to investigate the effect of vowels on oral reading accuracy, oral reading rate, and oral reading comprehension in Arabic. This may support the notion that the uniqueness of Arabic orthography adds some variables to be considered in the literature of science of reading as was stated by Abu Rabia (1997). Furthermore, Arabic is a diglossic language, with differences between standard and colloquial Arabic. Literary or standard Arabic is the medium of instruction and the language of most printed media whereas spoken Arabic is an everyday language (Abu-Rabia, 2000; Maamouri, 1998; Tahan, Cline, \& Messaoud-Galusi, 2011; Versteegh, 2001). The scripts used in the current study are literary Arabic sampled from the students' textbooks.

The genres used in the current study are sampled from the fifth and tenth grades textbooks in Saudi Arabia. In fact, there are many types of genres e.g., information, narration, persuasion, instructions, explanation, recount, reviews, reports, arguments, playscripts, and poetry and every genre type has its own characteristics i.e., purpose, structure, and language (Green, 2006; Hussien, 2009, 2011). The argument has been made that the structure of genre seems to affect reading comprehension as well as the condition of the genre, vowelized or unvowelized, doing this as stated above. It has been found that teaching text structure aids reading comprehension for both native and non-native readers (Carrell, 1984, 1987; Chang, 2002; Dymock, 1998, 1999, 2005; Meyer, 1987; Meyer, Brandt, \& Bluth, 1980; Meyer \& Rice, 1984; Pennsylvania State Department of Education [PSDE], 1997; Taylor, 1992; Troyer, 1994; Williams, 2005). In addition, students' prior schema of the structure of genre contributes to more effective comprehension of texts being read (Malmkjaer \& Anderson, 1991, p. 180; Swales, 1990, p. 84). The informational and poetic genres, sampled in the current study, are the dominant and distinctive types of texts in the participants' textbooks. The current study investigates the effect of the type of genre on oral reading accuracy, oral reading rate and oral reading comprehension in the fifth and tenth grades. The argument has been made that skilled readers in the tenth grade are expected to read accurately, rapidly and with comprehension depending on context, or without visible short vowels, whereas the fifth grade students need these visible short vowels (Abu-Rabia, 1997, 1999, 2001; Abu-Rabia \& Taha, 2006; Mahfoudhi et al., 2011; Taibah \& Haynes, 2011). In practice, scripts in the textbooks for students in the upper grades are unvowelized and texts in the textbooks for the first grades are vowelized. The current study investigated the validity and practicality of this issue which has scarcely been investigated.

\subsection{Reading Factors}

It is well-established in the literature that reading is a developmental process and hence, reading skills needs to be taught and improved simultaneously, gradually, and continuously throughout school grades. The current study investigated and examined the effect of vowels and type of genre on oral reading accuracy, oral reading rate, and oral reading comprehension in the fifth and tenth grades.

Firstly, oral reading accuracy is a significant indicating factor of reading fluency and it refers to the extent to which students read aloud according to the letter-sound conventions in Arabic (Hussien, 2014, p. 76). On the one hand, this requires students to read words with or without visible vowels and other diacritics and on the other hand, to recognize changes of the ends of a word as a result of its function and inflection in a sentence (Abu

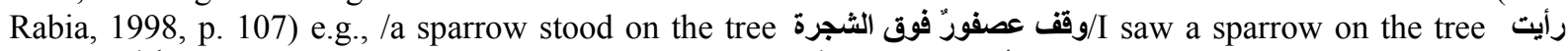
أمسكت بعصفور فوق الثجرة In caught a sparrow on the tree/. In addition, identical forms of a word, the phenomenon of homograph, are vowelized and pronounced differently according to meaning, as stated above. Vowels are a very important variable to be considered in reading Arabic script and therefore, reading words accurately in Arabic is not simply an autonomous process but a holistic cognitively demanding process that involves many variables, chief among them, vowels, syntax, vocabulary, and context as was stated by Abu Rabia (1998).

As mentioned earlier, accurate recognition of vowels in reading of Arabic script is a cognitively demanding process. The issue here is to what extent this process affects oral reading rate when scripts presented with or without visible vowels. This issue has not been addressed yet. Simply, oral reading rate refers to the number of words students read aloud per minute (Abu-Hajaj, 2006; Daane et al., 2005; Harris \& Sipay, 1980; White, 1995). The point here is that how many words children can read aloud per minute? This requires considering many variables, chief among them, the uniqueness of orthography (Abu-Hajaj, 2006; Hussien, 2014), and genre being 
read, as explained above. Arabic orthography, for example, is transparent, if presented vowelized, and is a homographic, if introduced unvowelized. It is also a consistent orthography, as stated earlier.

In spite of the fact that rapid (LaBerge \& Samuels, 1974; Mckenna, 2002; Nicholson \& Tan, 1999; Samuels, 1976, 2004; Samuels, Schermer, \& Reinking, 1992), and accurate reading (e.g., Denton et al., 2011; Schwanenflugel et al., 2006; Spooner, Baddeley, \& Gathercole, 2004) positively influence reading comprehension, comprehension of Arabic genres is also a cognitively demanding process. Readers devote more cognitive resources and effort to decode Arabic scripts which requires processing letters and vowels, visible or deduced, clarification of homographs, if presented without visible vowels, as explained above. According to automaticity theory, more focus on decoding, which is the case in the reading of Arabic text, negatively affects reading comprehension (Huey, 1908; LaBerge \& Samuels, 1974; Mckenna, 2002; Nicholson \& Tan, 1999; Samuels, 1976, 2004; Samuels, Schermer, \& Reinking, 1992). The current study investigated the impact of vowels on oral reading comprehension since, no attention is dedicated to this issue in reading Arabic orthography.

\subsection{The Context of the Study}

This study was carried out on the fifth and tenth grade Arabic-speaking students in Saudi Arabia public schools. The participants in this study were boys: 34 fifth graders and 51 tenth graders. In most Arab countries, scripts in textbooks are introduced vowelized to children in primary school and gradually texts are introduced unvowelized or partially vowelized throughout elementary and secondary school. The decision of whether to vowelize scripts in textbooks or not and at what educational stage, needs to be a research-based decision. In fact, there is some evidence derived from Abu Rabia's research on this issue, as stated above, but two points were noticed here: Abu Rabia's research was conducted in a non-Arab country and his participants were learning Hebrew (a Semitic language like Arabic) as a second language, and the decision needs a more robust baseline depending on different research and samples. The current study may or may not support Abu Rabia's results and implications. The researcher also noticed that scripts in textbooks other than the Arabic subject matter are introduced unvowelized which may affect reading accuracy, rate, or comprehension of these texts. A critical point to be made here is that textbooks not only involve textbooks in Arabic as a subject but, all types of textbooks in different subject matters e.g., science, mathematics, or social studies. This needs further research to examine different genres in different subject matters.

\section{Questions of the Study}

The current study addressed the following questions:

- What is the effect of the degree of transparency of Arabic orthography (shallow and deep) on oral reading rate, oral reading accuracy and oral reading comprehension of the fifth and tenth grade students?

- What is the effect of the genre (informational and poetic) on oral reading rate, oral reading accuracy and oral reading comprehension of the fifth and tenth grade students?

\section{Methods}

\subsection{Participants}

A purposeful sample of 85 Arabic-speaking students (34 fifth graders and 51 tenth graders) was selected from one educational district (Jazan district) in Saudi Arabia. Students were selected from two public schools: primary and secondary school. All participants are males as there are male and female schools in Saudi Arabia. This convenience sample serves the purposes of the current study as the researcher compared the data derived from the two versions of each reading measure, shallow and deep versions, completed by the same participants in the fifth grade or the tenth grade. An informed consent form was collected in writing from parents, the Jazan educational district and the schools where the sample was selected. In addition, oral consent was obtained from children.

\subsection{Measures}

The researcher developed two reading measures: the Fifth Grade Reading Measure (FGRM) and Tenth Grade Reading Measure (TGRM). Each measure consists of two versions, shallow/vowelized and deep/unvowelized, and involves two genres, informational and poetic. In addition, the two measures gauge the same three reading factors: oral reading rate, oral reading accuracy, and oral reading comprehension. The four excerpts (two in each measure) used in FGRM and TGRM were taken from the textbooks of Arabic in the fifth and tenth grades. These textbooks were developed by the Ministry of Education (2012) in Saudi Arabia and children had not studied 
these excerpts yet. In fact, informational and poetic genres are the dominant and represent different two genres in these textbooks.

The researcher made sure that FGRM and TGRM are valid and reliable measures by distributing them to ten teachers (five fifth grade teachers and five tenth grade teachers) of Arabic and requesting them to judge the measures in terms of the extent these measures operationalize the three factors of reading in question (Cohen, Manion, \& Morrison, 2007) and checking the clarity of them. In addition, the researcher applied the FGRM and TGRM to a pilot sample (20 fifth graders and 21 tenth graders) and calculated reliability using Split-Half technique, FGRM $=.89$ and TGRM $=.87$ which indicates that these measures are reliable.

\subsection{Procedures}

Repeated measures design was conducted. Each measure was administered in two sessions by the researcher with a week interval. A student completed one version of the measure in the first session and completed the other version after a week. To avoid the order effects of being shallow/vowelized or deep/unvowelized, the two versions of the measure were used alternately i.e., some students completed the shallow version firstly and then the deep version in the second session and some completed the unvowelized version in the first session and then the vowelized version in the second session. A student was requested to read aloud and answer six written multiple choices questions at the end of the reading of each excerpt. The administrator of the instrument calculated time, marked words that are read incorrectly.

\subsection{Analyses}

A Paired-Samples $\mathrm{T}$ Test was performed to explain the differences between shallow/vowelized and deep/unvowelized scripts on the reading factors and to clarify the difference between the two genres, informational and poetic, on the same reading factors.

\section{Results}

Addressing the first core question of the current study "What is the effect of the degree of transparency of Arabic orthography (shallow and deep) on oral reading rate, oral reading accuracy and oral reading comprehension of the fifth and tenth grade students?" A Paired-Samples T Test was performed as depicted in Table 1.

Table 1. The paired-samples $\mathrm{t}$ test results of the reading factors and reading conditions $(\mathrm{N}=85)$

\begin{tabular}{|c|c|c|c|c|c|c|c|c|c|c|c|c|}
\hline \multirow[t]{3}{*}{ Reading factors } & \multicolumn{12}{|c|}{ Reading conditions } \\
\hline & \multicolumn{2}{|c|}{$\begin{array}{l}\text { Shallow } \\
\text { informational genre }\end{array}$} & \multicolumn{2}{|c|}{$\begin{array}{l}\text { Deep informational } \\
\text { genre }\end{array}$} & \multirow[t]{2}{*}{$\mathrm{T}$} & \multirow[t]{2}{*}{ Sig. } & \multicolumn{2}{|c|}{$\begin{array}{l}\text { Shallow } \\
\text { poetic genre }\end{array}$} & \multicolumn{2}{|c|}{$\begin{array}{l}\text { Deep poetic } \\
\text { genre }\end{array}$} & \multirow[t]{2}{*}{$\mathrm{T}$} & \multirow[t]{2}{*}{ Sig. } \\
\hline & M & SD & M & SD & & & M & SD & M & SD & & \\
\hline $\begin{array}{l}\text { Oral reading } \\
\text { accuracy }\end{array}$ & 3.2 & 1.3 & 3.8 & 1.5 & 3.98 & .000 & 3.9 & 1.8 & 4.8 & 1.3 & 5.76 & .000 \\
\hline Oral reading rate & 86 & 31 & 93 & 27 & 3.64 & .000 & 76 & 28 & 81 & 26 & 2.34 & .022 \\
\hline $\begin{array}{l}\text { Oral reading } \\
\text { comprehension }\end{array}$ & 3.8 & 1.2 & 3 & 1.3 & 4.55 & .000 & 3.3 & 1 & 2.7 & 1.4 & 3.85 & .000 \\
\hline
\end{tabular}

Note: $* * * \mathrm{P}<.05$

Table 1 shows that there is a significant difference in the scores of oral reading accuracy for the shallow and deep genres. These results suggest that vowels have a positive effect in decreasing errors in reading both informational and poetic genres. Table 1 also indicates that there is a significant difference in the scores of oral reading comprehension for the shallow and deep genres. Vowels also have a positive effect in improving oral reading comprehension. Furthermore, Table 1 shows that there is a significant difference in the scores of oral reading rate for the shallow and deep genres. In contrast to results of oral reading accuracy and oral comprehension, vowels increase the time students spend in reading. Taken together, the results show that vowels seem to improve oral reading accuracy and oral reading comprehension but, they decelerate oral reading rate of the both genres in question. 
Answering the last key question of the current study "What is the effect of the genre (informational and poetic) on oral reading rate, oral reading accuracy and oral reading comprehension of the fifth and tenth grade students?" A Paired-Samples T Test was used as explained in Table 2.

Table 2. The paired-samples t test results of the reading factors and genres $(\mathrm{N}=85)$

\begin{tabular}{|c|c|c|c|c|c|c|}
\hline \multirow[t]{3}{*}{ Reading factors } & \multicolumn{4}{|c|}{ Genre } & \multirow[t]{3}{*}{$\mathrm{T}$} & \multirow[t]{3}{*}{ Sig. } \\
\hline & \multicolumn{2}{|c|}{ Informational } & \multicolumn{2}{|c|}{ Poetic } & & \\
\hline & M & SD & M & SD & & \\
\hline Oral reading accuracy & 7 & 2.5 & 8.7 & 2.8 & 6.682 & .000 \\
\hline Oral reading rate & 89 & 28 & 78 & 25 & 8.450 & .000 \\
\hline Oral reading comprehension & 6.9 & 2 & 6 & 2 & 4.381 & .000 \\
\hline
\end{tabular}

Note: $* * * \mathrm{P}<.05$

Table 2 shows that there is a significant difference in the scores of oral reading accuracy for the informational $(\mathrm{M}=7, \mathrm{SD}=2.5)$ and poetic $(\mathrm{M}=8.7, \mathrm{SD}=2.8)$ genres, $\mathrm{t}(84)=6.682, \mathrm{p}<.000$. This result suggests that students made more errors in reading the poetic genre than informational genre. In the same direction, Table 2 indicates that there is a significant difference in the scores of oral reading comprehension for the informational $(\mathrm{M}=6.9, \mathrm{SD}=2)$ and poetic $(\mathrm{M}=6, \mathrm{SD}=2)$ genres, $\mathrm{t}(84)=4.381, \mathrm{p}<.000$. This result implies that students gain more comprehension of the informational genre than poetic genre. Furthermore, Table 2 shows that there is a significant difference in the scores of oral reading rate for the informational $(\mathrm{M}=89, \mathrm{SD}=28)$ and poetic $(\mathrm{M}=$ $78, \mathrm{SD}=25$ ) genres, $\mathrm{t}(84)=8.450, \mathrm{p}<.000$. This result indicates that students are more rapid in reading the informational genre than poetic genre. To conclude, Table 2 indicates that there are significant differences in the scores of oral reading accuracy, oral reading rate, and oral reading comprehension for the informational and poetic genres.

\section{Discussion}

The first core findings of the current study are that vowels have a positive effect in improving oral reading accuracy and oral reading comprehension but, they decelerate oral reading rate by increasing the time students spend in oral reading. The positive effect of vowels on oral reading accuracy and oral reading comprehension, in the current study, is partially consistent with Abu Rabia's research who explains the importance of vowels in oral reading accuracy $(1997 ; 1998)$ and in silent reading comprehension (1999). A plausible explanation is that visible vowels moves the Arabic orthography from being deep to shallow orthography by which students can identify the unequivocal pronunciation and meaning of a word, as stated above. In other words, without these visible vowels students need to deduce them and eventually guess the correct meaning and pronunciation depending on context for reading. The current results are congruent with previous research not only in Arabic but also in Hebrew (a Semitic orthography like Arabic). In Arabic, children read vowelized genres more accurately than unvowelized texts (Abu-Rabia, 1998, 2001). In Hebrew, skilled adults read pointed texts more accurately than unpointed scripts (Abu-Rabia, 2001). In addition, vowelized scripts are more comprehensible than unvowelized texts in Arabic (Abu-Rabia, 1999, 2001), and pointed texts are more comprehensible than unpointed scripts in Hebrew (Abu-Rabia, 1999, 2001; Shimron, 1993; Shimron \& Sivan, 1994).

Interestingly and in contrast to improving oral reading accuracy and oral reading comprehension, using visible vowels decelerated oral reading rate and increased the time students spent in oral reading. This result is congruent with the fact that reading in Arabic orthography is a cognitively demanding process that involves processing letters and vowels, visible or deduced, as mentioned earlier. Although students deduce invisible vowels in reading deep scripts, this result seems to suggest that reading shallow/vowelized Arabic scripts is more cognitively demanding than reading deep/unvowelized texts. A sensible explanation is that students are visually-focused on visible vowels to recognize the proper meaning and pronunciation of a word. This explanation is sustained by the current results that students are more accurate and comprehensible in reading vowelized genres than unvowelized genres.

Two critical points to be made in this context: a theoretical and a practical point. Firstly, the current findings support Abu Rabia' research $(1997 ; 1998 ; 1999)$ with respect to vowels as a crucial variable to be added to the literature in science of reading. In fact, the science of reading is mainly informed and developed by studying 
Latin orthographies, usually English, which makes the science of reading at most the science of reading English (Perfetti \& Cao, 2013, p. 5). As consequences, reading research has limited relevance and implications for a universal science of reading (Share, 2008, p. 584). Therefore, the study of other alphabetic orthographies e.g., Arabic or Hebrew, and non- alphabetic orthographies e.g., Chinese or Japanese, widens understanding and horizons of science of reading. In recent years, there is a rising interest in studying of Arabic orthography, as explained above, and Chinese orthography (e.g., Anderson \& Chen, 2013; Anderson et al., 2013; Perfetti, Cao, \& Booth, 2013). For example, characters are more significant visual units than words in reading Chinese and meaning of these characters depends on context for reading (Chen, 1987; Luo, Chen, Deacon, Zhang, \& Yin, 2013). In a nutshell, the study of other orthographies, e.g., Arabic or Chinese, contributes to and has indispensible variables e.g., vowels in Arabic and characters in Chinese, to science of reading. Secondly, reading Arabic vowelized genres more accurately and with more comprehension but less rapidly has a very important and a wide-range implication in schools. It suggests that vowelization of scripts introduced in textbooks seems to improve reading accuracy and comprehension in primary and secondary schools.

The last key findings of the current study are that the characteristics of a genre, informational or poetic, has an effect on oral reading accuracy, oral reading rate and oral reading comprehension. Students, in the current study, read the informational genres more accurately, rapidly and with more comprehension than reading the poetic genres. The design, language and purpose of a genre seem to affect students' reading, as stated above. The informational and poetic genres are different in their structure that authors follow, and language that writers employ to convey their message. Therefore, a plausible explanation of the current results are that informational genres follow structures (e.g., description, cause and effect, or contrast) familiar to students and use direct and informative language whereas Arabic poetic genres pursue less familiar designs (16 different metres), utilize more literary, and metaphoric language (Wright, 1996), and involve many less frequent vocabularies (Abu Rabia, 1998, p. 115). In addition to these unique features of Arabic poetic genres, students are more exposed to informational genres than poetic genres not only in Arabic but also in other subject matters e.g., social studies, and science. In the literature, it is argued that a text structure has an effect on silent reading comprehension (Dymock, 1998, 1999; PSDE, 1997), and thus, these results add to the literature in science of reading with respect to the genre as a critical variable in oral reading rate, oral reading accuracy, and oral reading comprehension for primary and secondary school students. These findings also raise the issue of the importance of teaching students different genres and making students more familiar with the unique characteristics of each genre.

\section{Conclusion}

The current study adds to the literature in science of reading with respect to vowels as an important variable to be considered not only in oral reading accuracy and in silent reading comprehension but also, in oral reading rate, and oral reading comprehension for primary and secondary school students. It also proposes another variable to be taken into account in science of reading that is the genre which affects oral reading accuracy, oral reading rate, and oral reading comprehension. Furthermore, it is an important step in establishing research-based evidence for using vowels in Arabic orthography. In addition to these substantial theoretical propositions, the current study shows the importance of vowelizing Arabic scripts in students' textbooks in schools to improve oral reading accuracy and oral reading comprehension. To conclude, the uniqueness of Arabic orthography is an indispensible variable to science of reading. Further research is needed to examine different genres in different subject matters.

\section{Acknowledgement}

My sincere gratitude goes to my professor Mike Byram, Durham University, for his constant support and guidance and my colleague Mr. Khaled Homadi, Jazan University, for his help in conducting the field work.

\section{References}

Abu-hajaj, A. Z. (2006). معدل السر عة في القراءة لدى بعض الطالبات في مر احل التعليم العام و الجامعي [Reading rate of female students in the general and university education]. Journal of Reading and Literacy, 61, 130-170.

Abu-Rabia, S. (1997). The need for cross-cultural considerations in reading theory: The effects of Arabic sentence context in skilled and poor readers. Journal of Research in Reading, 20(2), 137-147. http://dx.doi.org/10.1111/1467-9817.00026

Abu-Rabia, S. (1998). Reading Arabic texts: Effects of text type, reader type and vowelization. Reading and Writing: An Interdisciplinary Journal, 10(2), 105-119. http://dx.doi.org/10.1023/A:1007906222227 
Abu-Rabia, S. (1999). The effect of Arabic vowels on the reading comprehension of second- and sixth-grade native Arab children. Journal of Psycholinguistic Research, 28(1), 93-101. http://dx.doi.org/10.1023/A:1023291620997

Abu-Rabia, S. (2000). Effects of exposure to literary Arabic on reading comprehension in a diglossic situation. Reading and Writing: An Interdisciplinary Journal, 13, 147-157. http://dx.doi.org/10.1023/A:1008133701024

Abu-Rabia, S. (2001). The role of vowels in reading semantic scripts: Data from Arabic and Hebrew. Reading and Writing: An Interdisciplinary Journal, 14, 39-59. http://dx.doi.org/10.1023/A:1008147606320

Abu-Rabia, S., \& Siegel, L. S. (1995). Different orthographies, different context effects: The effects of Arabic sentence context on skilled and poor readers, Reading Psychology, 16(1), 1-19. http://dx.doi.org/10.1080/0270271950160101

Abu-Rabia, S., \& Siegel, L. S. (2003). Reading skills in three orthographies: The case of trilingual Arabic-Hebrew-English-speaking Arab children. Reading and Writing: An Interdisciplinary Journal, 16, 611-634. http://dx.doi.org/10.1023/A:1025838029204

Abu-Rabia, S., \& Taha, H. (2006). Reading in Arabic orthography: Characteristics, research findings and assessment. In R. M. Joshi, \& P. G. Aaron (Eds.), Handbook of Orthography and Literacy (pp. 321-338). Mahwah; NJ: Lawrence Erlbaum Associates.

Anderson, R. C., \& Chen, X. (2013). Chinese reading development in monolingual and bilingual learners: Introduction to the special issue [Special issue]. Scientific Studies of Reading, 17(1), 1-4. http://dx.doi.org/10.1080/10888438.2012.729120

Anderson, R. C., Ku, Y. M., Li, W., Chen, X., Wu, X., \& Shu, H. (2013). Learning to see the patterns in Chinese characters [Special issue]. Scientific Studies of Reading, 17(1), 41-56. http://dx.doi.org/10.1080/10888438.2012.689789

Carrell, P. L. (1984). Evidence of a formal schema in second language comprehension. Language Learning, 34(2), 87-112. http://dx.doi.org/10.1111/j.1467-1770.1984.tb01005.x

Carrell, P. L. (1987). Content and formal schemata in ESL reading. TESOL Quarterly, 21(3), 461-481. http://dx.doi.org/10.2307/3586498

Chang, C. (2002). The reader effect (instruction/awareness of text structure) and text effect (well-structured vs. bad-structured texts) on first and second/foreign language reading comprehension and recall- what does research teach US? U.S., Indiana University. Retrieved June 26, 2010, from http://www.eric.ed.gov

Chen, H. C. (1987). Character detection in reading Chinese: Effect of context display format. Chinese Journal of Psychology, 29, 45-50.

Cohen, L., Manion, L., \& Morrison, K. (2007). Research Methods in Education (6th ed.). London: Routledge Falmer.

Daane, M. C., Campbell, J. R., Grigg, W. S., Goodman, M. J., Oranje, A., \& Goldstein, A. (2005). Fourth-grade students reading aloud: NAEP 2002 special study of oral reading (NCES 2006-469). Retrieved June 25, 2010, from http://www.eric.ed.gov

Denton, C. A., Barth, A. E., Fletcher, J. M., Wexler, J., Vaughn, S., Cirino, P. T., ... Francis, D. J. (2011). The relations among oral and silent reading fluency and comprehension in middle school: Implications for identification and instruction of students with reading difficulties. Scientific Studies of Reading, 15(2), 109-135. http://dx.doi.org/10.1080/10888431003623546

Dymock, S. J. (1998). A comparison study of the effects of text structure training, reading practice, and guided reading on reading comprehension. National Reading Conference Yearbook, 47, 90-102. Retrieved June 24, 2010, from http://www.eric.ed.gov

Dymock, S. J. (1999). Learning about text structure. In G. B. Thompson, \& T. Nicholson (Eds.), Learning to read (pp. 174-192). Newark, Delaware: International Reading Association.

Dymock, S. J. (2005). Teaching expository text structure awareness. The Reading Teacher, 59(2), 177-182. Retrieved from http://www.jstor.org/stable/20204334

Fadal-Allah, M. R. (2004). السر عة في القراءة: متغير اتها، وقياسها، وتنميتها and development]. Journal of Reading and Literacy, 34, 13-49. 
Furnes, B., \& Samuelsson, S. (2009). Preschool cognitive and language skills predicting kindergarten and grade1 reading and spelling: A cross-linguistic comparison. Journal of Research in Reading, 32(3), 275-292. http://dx.doi.org/10.1111/j.1467-9817.2009.01-393.x

Georgiou, G. K., Parrila, R., \& Papadopoulos, T. C. (2008). Predictors of word decoding and reading fluency across languages varying in orthographic consistency. Journal of Educational Psychology, 100(3), 566-580. http://dx.doi.org/10.1037/0022-0663.100.3.566

Goswami, U., Ziegler, J. C., \& Richardson, U. (2005). The effects of spelling consistency on phonological awareness: A comparison of English and German. Journal of Experimental Child Psychology, 92(4), 345-365. http://dx.doi.org/10.1016/j.jecp.2005.06.002

Green, M. (2006). Reading for Meaning. United Kingdom: Folens Publishers.

Harris, A. J., \& Sipay, E. R. (1980). How to increase reading ability (7th ed.). New York: Longman.

Hasbrouck, J., \& Tindal, G. A. (2006). Oral reading fluency norms: A valuable assessment tool for reading teachers. The Reading Teacher, 59(7), 636-644. http://dx.doi.org/10.1598/RT.59.7.3

Huey, E. B. (1908). The psychology and pedagogy of reading. New York: Macmillan.

Hussien, A. M. (2009). Designing a reading literacy curriculum for secondary school students in Egypt. (Published doctoral thesis. University of Durham, UK). Retrieved from http://etheses.dur.ac.uk/2116

Hussien, A. M. (2011). Reading literacy for adolescents: Linking theory to practice. Germany: LAP Lambert Academic Publishing.

Hussien, A. M. (2014). The indicating factors of oral reading fluency of monolingual and bilingual children in Egypt. International Education Studies, 7(2), 75-90. http://dx.doi.org/10.5539/ies.v7n2p75

LaBerge, D., \& Samuels J. S. (1974). Toward a theory of automatic information processing in reading. Cognitive Psychology, 6(2), 293-323. http://dx.doi.org/10.1016/0010-0285(74)90015-2

Lervåg, A., \& Hulme, C. (2010). Predicting the growth of early spelling skills: Are there heterogeneous developmental trajectories? Scientific Studies of Reading, 14(6), 485-513. http://dx.doi.org/10.1080/10888431003623488

Luo, Y. C., Chen, X., Deacon, S. H., Zhang, J., \& Yin, L. (2013). The Role of Visual Processing in Learning to Read Chinese Characters [Special issue]. Scientific Studies of Reading, 17(1), 22-40. http://dx.doi.org/10.1080/10888438.2012.689790

Maamouri, M. (1998). Language education and human development: Arabic diglossia and its impact on the quality of education in the Arab region. Paper Presented at the Mediterranean Development Forum of the World Bank, Marrakech, Morocco (September, pp. 3-6). Retrieved June 24, 2010, from http://www.eric.ed.gov

Mahfoudhi, A., Everatt, J., \& Elbeheri, G. (2011). Introduction to the special issue on literacy in Arabic [Special issue]. Reading and Writing: An Interdisciplinary Journal, 24(9), 1011-1018. http://dx.doi.org/10.1007/s11145-011-9306-y

Malmkjaer, K., \& Anderson, J. M. (1991). The linguistics encyclopedia. London: Routledge. http://dx.doi.org/10.4324/9780203432860

McKenna, M. C. (2002). Help for struggling readers: Strategies for grades 3-8. New York: The Duilford Press.

Meyer, B. J. F. (1987). Training use of top-level structure in expository text: increases in reading comprehension of young and old adults. Retrieved June 24, 2010, from http://www.research-gate,net/publication

Meyer, B. J. F., Brandt, D. M., \& Bluth, G. J. (1980). Use of top-level structure in text: Key for reading comprehension of ninth-grade students. Reading Research Quarterly, 16(1), 72-103. http://dx.doi.org/10.2307/747349

Meyer, B. J. F., \& Rice, G. E. (1984). The structure of text. In P. D. Pearson (Ed.), Handbook of reading research (vol. 1, pp. 319-352). New York: Longman.

Mohamed, W., Elbert, T., \& Landerl, K. (2011). The development of reading and spelling abilities in the first 3 years of learning Arabic. Reading and Writing: An Interdisciplinary Journal, 24(9), 1043-1060. http://dx.doi.org/10.1007/s11145-010-9249-8 
Nicholson, T., \& Tan, A. (1999). Proficient word identification for comprehension. In G. B. Thompson, \& T. Nicholson (Eds.), Learning to read (pp. 150-173). Newark, Delaware: International Reading Association.

Pennsylvania State Department of Education. (1997). The Pennsylvania assessment system reading instructional handbook. [Revised]. Pennsylvania State Department of Education: Harrisburg. Retrieved June 29, 2010, from http://www.eric.ed.gov

Perfetti, C., Cao, F., \& Booth, J. (2013). Specialization and universals in the development of reading skill: How Chinese research informs a universal science of reading [Special issue]. Scientific Studies of Reading, 17(1), 5-21. http://dx.doi.org/10.1080/10888438.2012.689786

Samuels, J. S. (1976). Automatic decoding and reading comprehension. Language Arts, 53(3), 323-325.

Samuels, J. S. (2004). Toward a theory of automatic information processing in reading, revisited. In R. B. Ruddell, \& N. J. Unrau (Eds.), Theoretical Models and Processes of Reading (5th ed., pp. 1127-1148). Newark, Delaware: International Reading Association.

Samuels, J. S., Schermer, N., \& Reinking, D. (1992). Reading fluency: Techniques for making decoding automatic. In S. J. Samuels, \& A. E. Farstrup (Eds.), What research has to say about reading instruction (2nd ed., pp. 124-144). Newark, Delaware: International Reading Association.

Schwanenflugel, P. J., Meisinger, E. B., Wisenbaker, J. M., Kuhn, M. R., Strauss, G. P., \& Morris, R. D. (2006). Becoming a fluent and automatic reader in the early elementary school years. Reading Research Quarterly, 4l(4), 496-522. http://dx.doi.org/10.1598/RRQ.41.4.4

Seymour, P. H. K., Aro, M., \& Erskine, J. M. (2003). Foundation literacy acquisition in European orthographies. British Journal of Psychology, 94(2), 143-174. http://dx.doi.org/10.1348/000712603321661859

Share, D. (2008). On the anglocentricities of current reading research and practice: The perils of overreliance on an "outlier" orthography. Psychological Bulletin, 134(4), 584-615. http://dx.doi.org/10.1037/0033-2909.134.4.584

Shimron, J. (1993). The role of vowels in reading: A review of studies of English and Hebrew. Psychological Bulletin, 114(1), 52-67. http://dx.doi.org/10.1037/0033-2909.114.1.52

Shimron, J., \& Sivan, T. (1994). Reading proficiency and orthography: Evidence from Hebrew and English. Language Learning, 44(1), 5-27. http://dx.doi.org/10.1111/j.1467-1770.1994.tb01447.x

Spooner, A. L., Baddeley, A. D., \& Gathercole, S. E. (2004). Can reading accuracy and comprehension be separated in the Neale analysis of reading ability? British Journal of Educational Psychology, 74(2), 187-204. http://dx.doi.org/10.1348/000709904773839833

Stanovich, K. E. (1980). Toward an interactive-compensatory model of individual differences in the development of reading fluency, Reading Research Quarterly, 16(1), 32-71. http://dx.doi.org/10.2307/747348

Stanovich, K. E. (1986). Matthew effects in reading: Some consequence of individual differences in the acquisition of literacy. Reading Research Quarterly, 4, 360-407. http://dx.doi.org/10.1598/RRQ.21.4.1

Stanovich, K. E. (1991). The psychology of reading: Evolutionary and revolutionary developments. Annual Review of Applied Linguistics, 12, 3-30. http://dx.doi.org/10.1017/S0267190500002129

Stanovich, K. E., \& Feeman, D. J. (1981). A longitudinal study of sentence context effects in second-grade children: Tests of an interactive-compensatory model. Journal of Experimental Child Psychology, 32(2), 185-199. http://dx.doi.org/10.1016/0022-0965(81)90076-X

Swales, J. M. (1990). Analysis: English in academic and research settings. Cambridge: Cambridge University Press.

Taibah, N. J., \& Haynes, C. W. (2011). Contributions of phonological processing skills to reading skills in Arabic speaking children [Special issue]. Reading and Writing: An Interdisciplinary Journal, 24(9), 1019-1042. http://dx.doi.org/10.1007/s11145-010-9273-8

Tahan, S., Cline, T., \& Messaoud-Galusi, S. (2011). The relationship between language dominance and pre-reading skills in young bilingual children in Egypt [Special issue]. Reading and Writing: An Interdisciplinary Journal, 24(9), 1061-1087. http://dx.doi.org/10.1007/s11145-011-9301-3 
Taylor, B. M. (1992). Text structure, comprehension, and recall. In S. J. Samuels, \& A. E. Farstrup (Eds.), What research has to say about reading instruction (2nd ed., pp. 220-235). Newark, Delaware: International Reading Association.

Troyer, S. J. (1994). The Effects of three instructional conditions in text structure on upper elementary students' reading comprehension and writing performance. Paper presented at the Annual Meeting of American Educational Reading association ( $75^{\text {th }}$, New Orleans, LA, April 4-8, 1994). Retrieved June 26, 2010, from http://www.eric.ed.gov

Versteegh, K. (2001). The Arabic language. Edinburgh: Edinburgh University Press.

Williams, J. P. (2005). Instruction in reading comprehension for primary-grade students: A focus on text structure. Journal of Special Education, 39(1), 6-18. http://dx.doi.org/10.1177/00224669050390010201

White, S. (1995). Listening to children reading aloud: Oral fluency. Retrieved June 24, 2010, from http://www.eric.ed.gov

Wright, W. (2011). A Grammar of the Arabic language (2nd ed.). New York, NY: Cosimo Classics.

\section{Copyrights}

Copyright for this article is retained by the author(s), with first publication rights granted to the journal.

This is an open-access article distributed under the terms and conditions of the Creative Commons Attribution license (http://creativecommons.org/licenses/by/3.0/). 